\section{Case Reports in Neurology}

Case Rep Neurol 2020;12:482-488

DOI: 10.1159/000510711

Published online: December 18, 2020
(C) 2020 The Author(s)

Published by S. 2 OPEN www.karger.com/crn

This article is licensed under the Creative Commons Attribution-NonCommercial 4.0 International License (CC BY-NC) (http://www.karger.com/Services/OpenAccessLicense). Usage and distribution for commercial purposes requires written permission.

\title{
Mixed Upper and Lower Motor Neuron Damage in Japanese Encephalitis Virus Infection
}

\author{
Ritwik Ghosh $^{a}$ Souvik Dubey ${ }^{b}$ Subhankar Chatterjee ${ }^{c}$ \\ Biman Kanti Ray ${ }^{b}$ Julián Benito-León ${ }^{d-f}$ \\ aDepartment of General Medicine, Burdwan Medical College and Hospital, Burdwan, India; \\ ${ }^{b}$ Department of Neuromedicine, Bangur institute of Neurosciences, Kolkata, India; \\ 'Department of General Medicine, Rajendra Institute of Medical Sciences, Ranchi, India; \\ dDepartment of Neurology, University Hospital "12 de Octubre", Madrid, Spain; "Centro \\ de Investigación Biomédica en Red sobre Enfermedades Neurodegenerativas (CIBERNED), \\ Madrid, Spain; fDepartment of Medicine, Complutense University, Madrid, Spain
}

\section{Keywords}

Japanese encephalitis · Japanese B encephalitis virus · Anterior horn cell · Motor neuron disease $\cdot$ Upper motor neuron $\cdot$ Lower motor neuron

\begin{abstract}
Cerebral manifestations in Japanese B encephalitis are well known. However, there are very few studies focusing on extra-cerebral manifestations, among which focal anterior horn cell involvement is exceedingly rare. We herein report a case of Japanese $B$ encephalitis with focal anterior horn cell involvement and unfurl how stepwise clinical approach and targeted investigations helped to solve the diagnostic conundrum. A 27-year-old female was admitted with fever, headache, altered sensorium, and convulsions. She tested positive for Japanese B encephalitis-IgM. Following conservative management, she regained consciousness after 5 days when neurological examination revealed marked cognitive impairment, medial convergence of eyeballs, upward gaze restriction, upper limbs dystonia with brisk tendon jerks, and flaccid paraparesis. A repeat neurological examination, on day 15 of admission, showed marked wasting and intermittent fasciculation in both lower limbs. Brain magnetic resonance imaging showed asymmetrical (right > left) bilateral thalamic and midbrain lesions, hyperintense on T2
\end{abstract}

\begin{tabular}{ll}
\hline & Julián Benito-León \\
Avda. de la Constitución 73 \\
portal $3,7^{\circ}$ Izquierda \\
ES-28821 Coslada, Madrid (Spain) \\
jbenitol67@gmail.com
\end{tabular}




\section{Case Reports in Neurology}

Case Rep Neurol 2020;12:482-488 DOI: 10.1159/000510711

(c) 2020 The Author(s). Published by S. Karger AG, Basel www.karger.com/crn

Ghosh et al.: Motor Neuron Damage in Encephalitis Virus Infection

and T2-fluid-attenuated inversion recovery (FLAIR)-weighted imaging with mild diffusion restriction on diffusion-weighted imaging and apparent diffusion coefficient map, suggestive of encephalitis. Nerve conduction study revealed decreased compound muscle action potentials exclusively in lower limbs with intact sensory nerve action potentials. Electromyogram showed chronic denervation potentials and presence of spontaneous activity in lower limbs, but not in upper limbs, indicative of focal anterior horn cell involvement. Prognosis of Japanese B encephalitis does not only depend on cerebral sequelae. Anterior horn cell involvement can dictate poor outcome and can easily be missed if not carefully dealt with.

(C) 2020 The Author(s)

Published by S. Karger AG, Basel

\section{Introduction}

Japanese B encephalitis is a vector-borne disease with high mortality and morbidity [1]. This understanding holds immense importance in the background of rural setting, where lack of diagnostic facilities and specialist care adds further on its burden [2]. Cerebral manifestations in Japanese B encephalitis are well known. [2]. However, there are very few studies focusing on extracerebral manifestations of Japanese B encephalitis virus infection, among which focal anterior horn cell involvement is exceedingly rare [3]. We herein report a case of Japanese B encephalitis with focal anterior horn cell involvement, which at onset was difficult to pick up. How stepwise approach, rational thinking, robust clinical examination, and targeted investigations helped to solve this diagnostic conundrum is the main theme of this article.

\section{Case Report}

A 27-year-old woman, permanent resident of Birbhum district of West Bengal, was admitted to the emergency department with altered consciousness and recurrent generalized tonic-clonic seizures since morning. Brief background history suggested that she had headache and high-grade fever with chills and rigors for last 4 days. After securing airway, breathing, establishment of circulatory supports and seizure control, a brief systemic examination was done. She was extremely restless and had a Glasgow coma scale score of 9 (E2M4V3). She was febrile $\left(39.6^{\circ} \mathrm{C}\right)$ with neck stiffness, and positive Kernig's and Brudzinski's signs. There was bilateral miosis and sluggish reaction to light. Increased tone and brisk deep tendon reflexes were noted in the upper limbs, whereas flaccidity and areflexia were noted in lower extremities, being plantar responses absent. Other systemic examinations were within normal limit. There was no clue of any poisoning, connective tissue disorders, bite mark, or rash. She belonged to an endemic zone of Japanese B encephalitis and malaria, but she was not vaccinated against the former [4]. Drugs, recent vaccination, addiction, and family history were non-contributory. A working diagnosis of acute encephalitis syndrome was made. At admission, intravenous lorazepam (4 mg, slow bolus) was given to stop seizures. Intravenous antibiotic (ceftriaxone $4 \mathrm{~g}$ /day) and antiviral (acyclovir $3 \mathrm{~g} /$ day) were given before confirmation of etiology on empirical basis. She was put on intravenous levetiracetam $(2 \mathrm{~g} /$ day) for seizure prophylaxis. Intracranial pressure measurement was not possible in our set up. Intravenous

\section{Karger'=}




\section{Case Reports in Neurology}

Case Rep Neurol 2020;12:482-488

DOI: 10.1159/000510711

(c) 2020 The Author(s). Published by S. Karger AG, Basel www.karger.com/crn

Ghosh et al.: Motor Neuron Damage in Encephalitis Virus Infection

mannitol was given to decrease intracranial pressure $(20 \%, 5 \mathrm{~mL} / \mathrm{kg}$ in $30 \mathrm{~min}$ as first dose; then $2.5 \mathrm{~mL} / \mathrm{kg}$ at 6 -h intervals up to $48 \mathrm{~h}$ ).

Routine metabolic panel including complete hemogram, glucose, renal, liver, thyroid function tests, and lipid profile were normal. Tests for malarial parasites and dengue virus were negative. Brain magnetic resonance imaging showed asymmetrical (right > left) bilateral thalamic and midbrain lesions, hyperintense on T2 and T2-fluid-attenuated inversion recovery (FLAIR)-weighted imaging with mild diffusion restriction on diffusion-weighted imaging and apparent diffusion coefficient map, suggestive of encephalitis (Fig. 1). Lumbar puncture revealed a high opening pressure of $40 \mathrm{~cm} \mathrm{H}_{2} \mathrm{O}$ (normal: 7-18 $\mathrm{cm} \mathrm{H}_{2} \mathrm{O}$ ). Cerebrospinal fluid showed pleocytosis (18 white blood cells per $\mathrm{mm}^{3}$ [normal: $0-5$ per $\mathrm{mm}^{3}$ ] being all lymphocytes), elevated protein (60 mg/dL [normal: $15-45 \mathrm{mg} / \mathrm{dL}])$, and normal glucose concentrations. Paired sera for Japanese B encephalitis-IgM by enzyme-linked immunosorbent assay method were positive. Paired sera for other viruses including herpes simplex virus, varicella zoster virus, enterovirus, and dengue were negative, as well as scrub typhus-IgM and Leptospira-IgM. Urine toxicology screening was negative. Connective tissue disorders were ruled out by necessary investigations.

A detailed neurological examination was possible only after 5 days of admission when she regained consciousness. She had dysarthric speech, intermittent irrelevant and incoherent talks with stated facts that never actually happened. She had a low mood most of the time with intermittent anger outbursts and poor attention. It was evident that there was anterograde amnesia, impairment of registration and word recall along with poor attention. In fact, impaired attention made detailed cognitive evaluation difficult. There was medial convergence of eyeballs and upward gaze restriction. There was no involvement of pupils and other cranial nerves. Upper limbs had dystonic posturing and cogwheel rigidity (left > right). The power of bilateral upper limbs was $4+/ 5$ on medical research council (MRC) scale. All deep tendon reflexes of upper limbs were brisk. She also showed flaccid, areflexic paraparesis with absent plantar responses. The power of left lower limb was $0 / 5$, while that of right lower limb was $1 / 5$ (MRC). There was no involvement of sensory system, bladder, bowel, or autonomic nervous system. A repeat neurological examination, on day 15 of admission, showed marked wasting (distal > proximal, left > right), and intermittent fasciculation in both lower limbs. To evaluate the cause of flaccid, areflexic paraparesis, contrast enhanced MRI of whole spine was performed and showed no abnormality. Nerve conduction study revealed decreased compound muscle action potentials exclusively in lower limbs (left more than right) with intact sensory nerve action potentials. Electromyogram (EMG) showed chronic denervation potentials and presence of spontaneous activity in lower limbs, but not in upper limbs, indicative of focal anterior horn cell involvement.

After 6 months of follow-up, there was a significant improvement in Glasgow coma scale (15/15). However, detailed cognitive evaluation still revealed persistent frontal subcortical type impairment. Her upper limb dystonia responded well with trihexyphenidyl and clonazepam. Cramps in the lower limb slightly improved with symptomatic management with gabapentin, methylcobalamin, and vitamin E. During the last visit, the power of her left and right lower limbs was $1 / 5$ and 3/5 (MRC), respectively; meanwhile, bilateral upper limb power was $4+/ 5$ with normal muscle tone.

\section{Karger'=}




\section{Case Reports in Neurology}

Case Rep Neurol 2020;12:482-488

DOI: 10.1159/000510711

(c) 2020 The Author(s). Published by S. Karger AG, Basel www.karger.com/crn

Ghosh et al.: Motor Neuron Damage in Encephalitis Virus Infection

\section{Discussion}

Initial presentation with acute onset fever for 4 days, behavioral abnormality with changes in mental status and new onset seizures fulfilled the case definition for an acute encephalitis syndrome [5]. Differential diagnoses include Japanese B encephalitis, dengue, cerebral malaria, scrub typhus meningitis, leptospirosis, other viral, bacterial, or fungal meningoencephalitis, vascular phenomenon, metabolic encephalopathies, autoimmune encephalitis, and connective tissue disorders with central nervous system involvement. Positive Japanese B encephalitis-IgM and typical lesions on brain MRI confirmed the diagnosis of Japanese B encephalitis in our patient.

Dystonic posturing of the upper limbs, cognitive dysfunction, and medial convergent gaze was explained by involvement of bilateral thalamus, midbrain, and substantia nigra [6, 7]. After she gained consciousness, it was unfurled that she had a disseminated cranio-spinal axis problem. Upper motor neuron type of weakness in upper limbs and lower motor neuron type of weakness in lower limbs led us to think of: (1) infective encephalomyelitis (i.e., postinfectious acute disseminated encephalomyelitis or post-viral acute longitudinally extensive transverse myelitis) involving dorsal cord in prolonged shock stage [8-10]; (2) other conditions such as tuberculosis, lymphoma, carcinomatous infiltration, neurosarcoidosis, and so on, which may involve brain and patchy arachnoiditis simultaneously; (3) acute motor axonal neuropathy involving lower limbs in particular after a viral infection [11]; (4) post-viral anterior horn cell damage resulting in asymmetric lower motor neuron weakness in lower extremities similar to poliomyelitis [12,13]; (5) critical illness neuropathy; and (6) nutritional deficiency neuropathy. However, from spinal MRI findings, electrophysiological studies, and logical deduction, it became apparent that she had a pure lower motor neuron axis pathology in lower limbs. Differential diagnoses considered were anterior horn cell disease, plexopathy, motor-predominant polyradiculoneuropathy, peripheral neuropathy, neuromuscular junction disorder, and muscle disorders. Among them, anterior horn cell disease seemed to be the most befitting (asymmetric weakness, distal weakness more than proximal weakness, intermittent fasciculations, marked wasting, spontaneous activity and denervation potentials in EMG, and weakness without sensory, autonomic, or bladder-bowel involvement).

Thalamus is the most involved area of the brain in Japanese B encephalitis infection, especially in endemic areas [14]. Albeit there is often bilateral thalamic involvement, it usually remains asymmetric most of the times, unlike in most neurodegenerative, metabolic, and deposition diseases [15]. Other areas than thalamus, such as basal ganglia, midbrain, and hippocampus may also be involved $[14,16]$.

Anterior horn cell involvement in Japanese B encephalitis is exceedingly rare, but not unheard of. In their pioneering study, Misra and Kalita [3] demonstrated a cluster of patients (7 out of 12) having monophasic anterior horn cell involvement as a part of Japanese B encephalitis encephalomyelitis. Marked muscle wasting and EMG findings were noted by 2 weeks and 4 weeks, respectively, in their cohort of patients [3]. The authors also suggested that recovery from neurological deficit was related to the extent of the spinal cord involvement [3]. Hence, persisting neurological deficit and poor outcome in our patient could be explained by anterior horn cell involvement of the whole lumbar segment. A study performed by the same group of researchers found motor-evoked potential abnormalities in 34 out of 46 patients [17]. These abnormalities were associated with an overall worse outcome [17]. Anterior horn cell involvement by Japanese B encephalitis virus has also been documented by this group of researchers in other reports $[6,18,19]$; these findings need confirmation by studies recruiting patients

\section{Karger'=}




\section{Case Reports in Neurology}

\begin{tabular}{l|l}
\hline Case Rep Neurol 2020;12:482-488 \\
\hline DOI: 10.1159/000510711 & $\begin{array}{l}\text { @ 2020 The Author(s). Published by S. Karger AG, Basel } \\
\text { www.karger.com/crn }\end{array}$ \\
\hline
\end{tabular}

Ghosh et al.: Motor Neuron Damage in Encephalitis Virus Infection

from different endemic zones. Results from electrophysiological studies in a cohort of 22 acute flaccid paralysis Vietnamese children demonstrated that Japanese B encephalitis infection was present among 12 patients [12]. Kim et al. [20] reported a case of a 44-year-old male patient having lower motor neuron type of weakness masquerading as Guillain-Barré syndrome, affecting all limbs (upper > lower) with respiratory muscles involvement, typical EMG findings, and post-Japanese B encephalomyelitis contributing to cervical cord syrinx formation. A study by Thuong et al. [21] found three Japanese B encephalitis-infected patients with novel single nucleotide polymorphisms in the superoxide dismutase 1 gene. They postulated that free-radical-induced damage to anterior horn cell may be responsible for acute flaccid paralysis in Japanese B encephalitis cases [21]. Superoxide dismutase 1 mutation makes the infected person more likely to manifest anterior horn cell disease as the free-radical mediated destruction to anterior horn cells is poorly tolerated in these cases [21].

\section{Conclusions}

Apart from describing an exceedingly rare manifestation of Japanese B encephalitis, this case highlights how to approach a case where there is simultaneous involvement of upper motor neuron type paresis of upper limbs along with lower motor neuron type paresis of lower limbs. Though central nervous system involvement is a sign of Japanese B encephalitis, peripheral nervous system examination is to be done carefully as its involvement, though rare, is very costly. Prognosis of Japanese B encephalitis does not only depend on cerebral sequelae. Anterior horn cell involvement can dictate poor outcome and can easily be missed if not carefully dealt with.

\section{Statement of Ethics}

Our patient gave her written informed consent for publication of the article (including imaging results).

\section{Conflict of Interest Statement}

The authors have no conflicts of interest to declare.

\section{Funding Sources}

None.

\section{Author Contributions}

R.G. and S.D. diagnosed the case and were involved in the care of the patient. RG, SD, and S.C. were involved in writing the draft which was further modified after getting critical inputs from B.K.R. and J.B.-L. All authors agreed upon the final version of the article.

\section{Karger'=}




\section{Case Reports in Neurology}

\begin{tabular}{l|l}
\hline Case Rep Neurol 2020;12:482-488 \\
\hline DOI: 10.1159/000510711 & $\begin{array}{l}\text { ○ 2020 The Author(s). Published by S. Karger AG, Basel } \\
\text { www.karger.com/crn }\end{array}$ \\
\hline
\end{tabular}

Ghosh et al.: Motor Neuron Damage in Encephalitis Virus Infection

\section{References}

1 Solomon T, Dung NM, Kneen R, Gainsborough M, Vaughn DW, Khanh VT. Japanese encephalitis. J Neurol Neurosurg Psychiatry. 2000 Apr;68(4):405-15.

2 Tiwari S, Singh RK, Tiwari R, Dhole TN. Japanese encephalitis: a review of the Indian perspective. Braz J Infect Dis. 2012 Nov-Dec;16(6):564-73. https://doi.org/10.1016/j.bjid.2012.10.004.

3 Misra UK, Kalita J. Anterior horn cells are also involved in Japanese encephalitis. Acta Neurol Scand. 1997 Aug;96(2):114-7.

4 Bandyopadhyay B, Bhattacharyya I, Adhikary S, Mondal S, Konar J, Dawar N, et al. Incidence of Japanese encephalitis among acute encephalitis syndrome cases in West Bengal, India. BioMed Res Int. 2013;2013:896749.

5 Ghosh S, Basu A. Acute Encephalitis Syndrome in India: The Changing Scenario. Ann Neurosci. 2016 Sep;23(3):131-3.

6 Misra UK, Kalita J, Jain SK, Mathur A. Radiological and neurophysiological changes in Japanese encephalitis. J Neurol Neurosurg Psychiatry. 1994 Dec;57(12):1484-7.

7 Misra UK, Kalita J. Overview: Japanese encephalitis. Prog Neurobiol. 2010 Jun;91(2):108-20.

8 Verma R, Praharaj HN, Patil TB, Giri P. Acute transverse myelitis following Japanese encephalitis viral infection: an uncommon complication of a common disease. BMJ Case Rep. 2012 Sep;2012:bcr2012007094.

9 Mohta S, Ray A, Sharma SK, Vyas S. Longitudinally extensive transverse myelitis (LETM) in a case of Japanese encephalitis with an unexpected complication. J Vector Borne Dis. 2017 Jul-Sep;54(3):291-3.

10 Ankur Nandan V, Nilesh K, Dibyaranjan B, Ashutosh T, Ravi A, Arvind A. Acute transverse myelitis (ascending myelitis) as the initial manifestation of Japanese encephalitis: a rare presentation. Case Rep Infect Dis. 2013;2013:487659.

11 Bandyopadhyay D, Ganesan V, Choudhury C, Kar SS, Karmakar P, Choudhary V, et al. Two Uncommon Causes of Guillain-Barré Syndrome: Hepatitis E and Japanese Encephalitis. Case Rep Neurol Med. 2015;2015:759495.

12 Solomon T, Kneen R, Dung NM, Khanh VC, Thuy TT, Ha DQ, et al. Poliomyelitis-like illness due to Japanese encephalitis virus. Lancet. 1998 Apr;351(9109):1094-7.

13 Chung CC, Lee SS, Chen YS, Tsai HC, Wann SR, Kao CH, et al. Acute flaccid paralysis as an unusual presenting symptom of Japanese encephalitis: a case report and review of the literature. Infection. 2007 Feb;35(1):302.

14 Kumar S, Misra UK, Kalita J, Salwani V, Gupta RK, Gujral R. MRI in Japanese encephalitis. Neuroradiology. 1997 Mar;39(3):180-4.

15 Smith AB, Smirniotopoulos JG, Rushing EJ, Goldstein SJ. Bilateral thalamic lesions. AJR Am J Roentgenol. 2009 Feb;192(2):W53-62.

16 Verma R. MRI features of Japanese encephalitis. BMJ Case Rep. 2012 Jul;2012:bcr0320126088.

17 Kalita J, Misra UK. Neurophysiological changes in Japanese encephalitis. Neurol India. 2002 Sep;50(3):262-6.

18 Misra UK, Kalita J, Goel D, Mathur A. Clinical, radiological and neurophysiological spectrum of JEV encephalitis and other non-specific encephalitis during post-monsoon period in India. Neurol India. 2003 Mar;51(1):55-9.

19 Pradhan S, Gupta RK, Singh MB, Mathur A. Biphasic illness pattern due to early relapse in Japanese-B virus encephalitis. J Neurol Sci. 2001 Jan;183(1):13-8.

20 Kim YM, Kim Y, Oh J, Kim HR, Park JH. Prolonged Motor Weakness With Syringomyelia in Japanese Encephalitis: A Case Study. Ann Rehabil Med. 2015 Oct;39(5):821-5.

21 Thuong NT, Dunstan SJ, Dung NM, Charlieu JP, Loan HT, Wills B, et al. Polymorphisms of the gene coding for copper/zinc superoxide dismutase (SOD1) in patients with Japanese encephalitis. Ann Trop Med Parasitol. 2006 Oct;100(7):631-6. 


\section{Case Reports in Neurology}
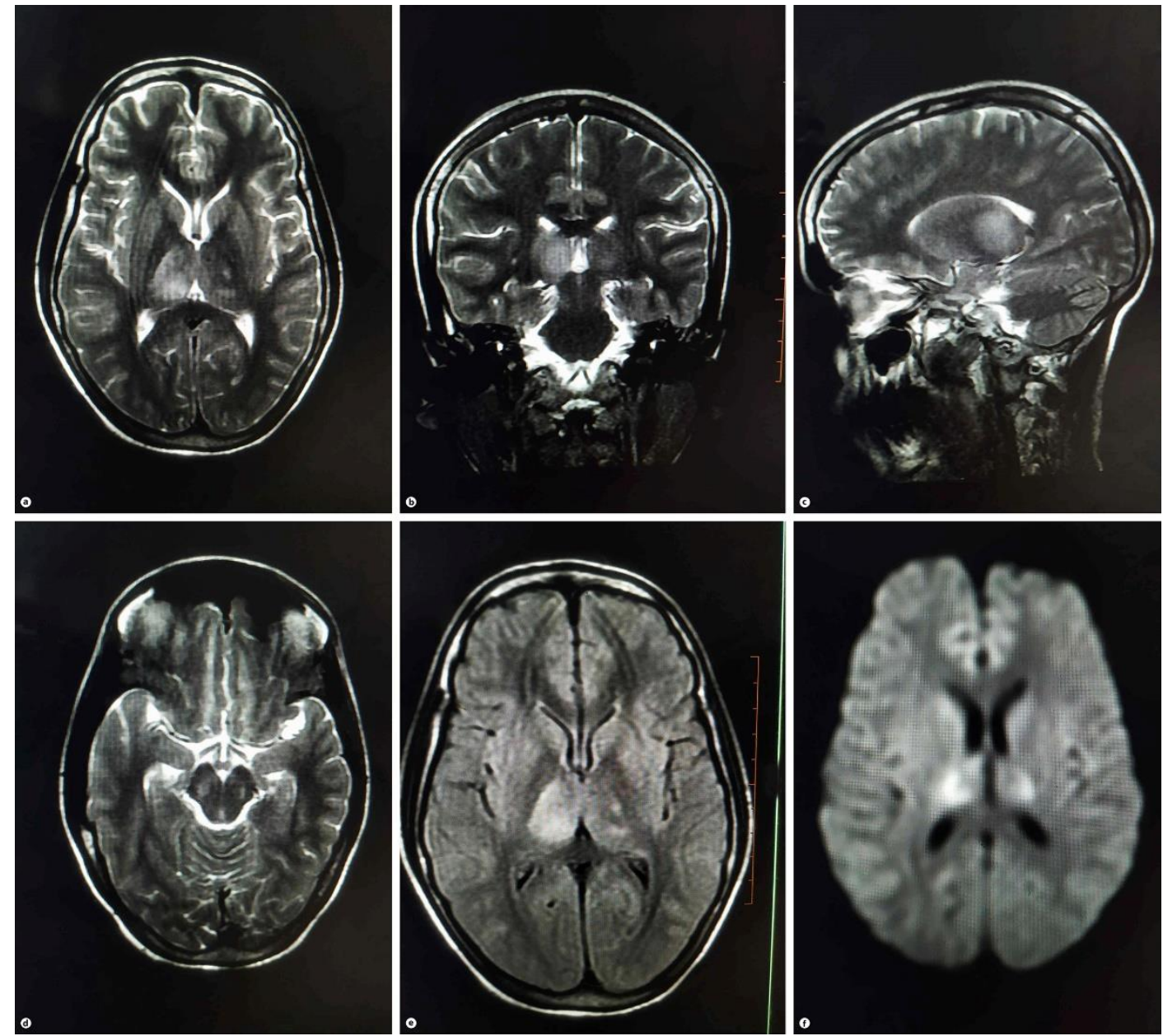

Fig. 1. Brain magnetic resonance imaging showed asymmetrical (right > left) bilateral thalamic and midbrain lesions, hyperintense on T2 and T2-fluid-attenuated inversion recovery (FLAIR)-weighted imaging with mild diffusion restriction on diffusion-weighted imaging, suggestive of encephalitis. a Axial T2weighted imaging. b Coronal T2-weighted imaging. c Sagittal T2-weighted imaging. d Axial T2-weighted imaging. e Axial T2-FLAIR. f Axial diffusion-weighted imaging. 